\title{
1. COASTAL PLAIN DRILLING AND THE NEW JERSEY SEA-LEVEL TRANSECT ${ }^{1}$
}

\author{
Kenneth G. Miller ${ }^{2,3}$
}

\begin{abstract}
A triad of processes controls the marine stratigraphic record: changes in sea level, tectonics, and sediment supply. Whereas the stratigraphic record may be objectively divided into sequences (unconformity-bounded units), the relative role of these three processes on development of passive continental margin sequences remains controversial. Three tasks must be accomplished before extracting process from the passive margin signal: the sequences must be identified, dated, and the facies changes within them mapped. The New Jersey Sea-level Transect (Ocean Drilling Program Leg 150X onshore drilling, Leg 150 slope drilling, and Leg 174A shelf drilling) has begun this task. The New Jersey Coastal Plain Drilling Project (Leg 150X) has completed boreholes at Island Beach (total depth $1223 \mathrm{ft}$ [372.7 m]; April-May, 1993), Atlantic City (total depth $1452 \mathrm{ft}$ [442.6 m]; June-August, 1993), and Cape May (total depth $1500 \mathrm{ft} \mathrm{[457.2} \mathrm{m];} \mathrm{March-April,} \mathrm{1994).} \mathrm{The} \mathrm{papers} \mathrm{contained} \mathrm{in}$ this volume present detailed lithostratigraphic, well-log, core-log, magnetostratigraphic, biostratigraphic, chemostratigraphic, paleoenvironmental, and hydrogeologic studies conducted on these boreholes. This introductory chapter outlines the general goals and strategies of onshore drilling in the context of the New Jersey Sea-level Transect, provides an overview of the material recovered onshore by Leg 150X in 1993-1994, and discusses the nature of post-drilling studies and the need for future work. Highlights of Leg 150X include the following:

1. Studies herein develop a chronology of late middle Eocene to middle Miocene onshore sequence boundaries, correlate them with major $\delta^{18} \mathrm{O}$ increases, and confirm that these unconformities were formed by global sea-level lowerings.

2. Comparison of New Jersey sequences with the Exxon syntheses shows that the Exxon Eocene to middle Miocene sequences are recorded on the New Jersey Margin where their ages are well constrained.

3. A sequence stratigraphic framework was obtained for the Paleocene to middle Miocene by integrating chronologic, lithostratigraphic, well-log, core-log, benthic foraminiferal biofacies, and isotopic studies. These studies include evaluation of unconformities and flooding surfaces, delineating systems tract variations within sequences, and estimating water depth variations within sequences.

4. Other studies address hydrostratigraphy, pore-water quality, pore-water isotopic composition, clay mineralogy, silica diagenesis, core-log/well-log integration, biostratigraphy, palynology, and climate.
\end{abstract}

\section{THE NEW JERSEY SEA-LEVEL TRANSECT}

Debates about the importance of tectonics vs. eustatic controls on the sedimentary record have a long history. Suess (1885) attributed sedimentary cycles to sea-level change, whereas Stille (1924), Grabau (1936), and Sloss (1963) favored tectonic controls (see Fairbridge, 1961, for review). Studies at Exxon Production Research (EPR; Vail et al., 1977; Haq et al., 1987) broke new ground both in recognizing unconformities and in relating them to global sea-level (eustatic) change. Vail et al. (1977) first used seismic profiles to identify sequences and to estimate the magnitude and ages of past sea-level changes. Haq et al. (1987) and Posamentier et al. (1988) extended these studies to outcrops and well logs, providing a detailed Triassic to Holocene chronology of sequences and eustatic changes. The work of EPR has remained controversial (Miall, 1991), in part because most of the data on which it is constructed are not publicly available, although portions have been released (e.g., Greenlee and Moore, 1988; Greenlee et al., 1988, 1992; Loutit et al., 1988).

Sequences are fundamental building blocks of the stratigraphic record and may be objectively recognized (for discussion see Christie-Blick et al., 1990), although the link between sequences and eustasy is controversial. Eustasy, tectonics (including thermal subsidence, isostasy, compaction, and flexure; see Reynolds et al., 1991 for elaboration), and sediment supply are the primary processes that control the formation of sequences. However, the relative roles of these

${ }^{1}$ Miller, K.G., and Snyder, S.W. (Eds.), 1997. Proc. ODP, Sci. Results, 150X: College Station, TX (Ocean Drilling Program).

${ }^{2}$ Department of Geological Services, Rutgers University, Piscataway, NJ 08855, U.S.A.kgm@ rci.rutgers.edu

${ }^{3}$ Lamont-Doherty Earth Observatory of Columbia University, Palisades, NY 10964 , U.S.A. processes are not fully understood, and the relationship of sequences and facies successions to sea level must be established through empirical studies and modeling efforts (both forward and inverse; Reynolds et al., 1991).

There are two ways to extract the global sea-level signal from local and regional sequence stratigraphic records of passive continental margins. Both first require dating sequence boundaries on a given margin that, in turn, provides a chronology of base-level lowerings (Christie-Blick et al., 1990). In the first method, inverse models (e.g., backstripping of Watts and Steckler, 1979, or the geometrical techniques of Greenlee et al., 1988) can be used to estimate relative sealevel history; a eustatic component may be estimated by comparing this chronology of sequences and relative sea-level history with other margins, particularly those in other tectonic settings. In the second method, global sea level is estimated using independent techniques (e.g., oxygen isotopic or atoll records; Imbrie et al., 1988); this record is then compared to ages of sequence boundaries, facies variations, and the relative sea-level record of a given margin to evaluate the response of sedimentation to a known forcing. This latter method is mostly restricted to the younger (last $100 \mathrm{~m}$.y. or so) record (ChristieBlick et al., 1990).

In a series of meetings between 1987 and 1992 (Second Conference on Scientific Ocean Drilling, Imbrie et al., 1988; Sea-level Workshop, Watkins and Mountain, 1990; Chapman Conference on Long-term Sea level Change, Sahagian and Watts, 1991; and Sealevel Working Group, 1992), a consensus developed in the academic community that borehole transects on passive margins are needed to improve knowledge of the timing and magnitude of past eustatic changes and their relationships to sequences. Three crucial time intervals were identified: the Oligocene to Holocene "Icehouse World," when glacioeustatic changes were clearly operating; the Cretaceous "Greenhouse World," which lacked significant ice sheets; 
and the Paleocene-Eocene "Doubthouse World," a time for which debate continues over the existence of ice sheets.

The Oligocene to Holocene "Icehouse World" is a particularly interesting interval for sea-level studies because the timing of unconformities can be compared with a glacioeustatic proxy afforded by the $\delta^{18} \mathrm{O}$ record. Oxygen isotope values recorded by foraminifers are a function of the marine temperature and the seawater $\delta^{18} \mathrm{O}$ value $\left(\delta_{w}\right)$ in which the organisms lived. Glacioeustatic fluctuations cause global $\delta_{w}$ changes that are recorded by benthic and planktonic foraminifers; the challenge is to isolate the ice-volume signal from temperature and local isotopic changes. Following Pleistocene conventions (Shackleton and Opdyke, 1973), synchronous increases in both benthic and low-latitude planktonic foraminiferal $\delta^{18} \mathrm{O}$ signals can be used as a proxy for pre-Pleistocene ice-volume changes. Miller et al. (1987, 1991) and Wright and Miller (1992) identified 12 Oligoceneearly late Miocene $\delta^{18} \mathrm{O}$ increases, interpreted them as glacioeustatic lowerings, and correlated them with 12 sequence boundaries (= inferred eustatic lowerings) of Haq et al. (1987; Fig. 3). Miller et al. (1996b) identified one additional middle Miocene increase (Mi3a, 14.4 Ma or 14.7 Ma using the time scales of Berggren et al., 1985 or 1995, respectively), and Pekar and Miller (1996) and Pekar et al. (Chapter 15, this volume) identified at least three additional smaller amplitude Oligocene increases.

To address sequences and sea-level changes on a passive margin, K.G. Miller, G.S. Mountain, and N. Christie-Blick designed the "New Jersey Sea-level Transect" as a series of boreholes from the onshore New Jersey Coastal Plain across the shelf to the slope and rise (Figs. 1, 2; see summary by Miller and Mountain, 1994). New Jersey was chosen to be the first transect of a siliciclastic margin because of the excellent data available for planning (e.g., Greenlee et al., 1988, 1992), well-developed Oligocene-Holocene seismic geometries (Mountain, Miller, Blum, et al., 1994), relatively simple tectonic history (Steckler and Watts, 1982), and good biostratigraphic and Srisotope stratigraphic control (e.g., Sugarman et al., 1993). The transect continued one begun by Deep Sea Drilling Project (DSDP) Legs 93 and 95, which drilled on the lower slope and rise. Although this DSDP drilling was designed to test the "Vail sea-level curve," it failed to recover much of the critical Oligocene to middle Miocene section (Poag, Watts, et al., 1987; van Hinte, Wise, et al., 1987).

The primary goals of the New Jersey Transect are (1) to date major "Icehouse" (Oligocene-Holocene) sequences, (2) to compare the timing of these sequences with ages predicted from the oxygen isotope proxy of glacioeustasy, (3) to estimate the amplitudes and rates of the sea-level change, and (4) to evaluate sequence stratigraphic models (e.g., the systems tracts of Posamentier et al., 1988).

The first step in the transect was to trace major sequences recognized in seismic profiles from the shelf to the slope where they were dated by Leg 150 (Fig. 1; Sites 902-904, 906; Mountain, Miller, Blum, et al., 1994; Miller et al., 1996b). Unfortunately, concerns over the hazards of drilling (e.g., shallow gas) led to disapproval of Leg 150 sites in less than $200 \mathrm{~m}$ water depth. No continuously cored sites are available on the modern shelf, the region most likely to record former sea-level and facies changes. The sedimentary expression of sequences on the slope is muted, because of relatively uniform Oligocene to Miocene lithologies (silty clays); in addition, the sites are too far downdip to be used to estimate the amplitudes and rates of relative sea-level change. Thus, Leg 150 drilling did not address two of the primary goals of the transect, estimating amplitudes/rates and sequence architecture. These goals can be addressed only by drilling updip across the modern shelf and coastal plain.

The New Jersey Coastal Plain drilling project (Leg 150X; Fig. 2) began in 1993 in concert with Leg 150 slope drilling. Drilling onshore not only provides another setting (one with shallow water environments and low accommodation) in which to date specific sequences, but it also provides shallow-water (neritic and shallower) facies information that allows evaluation of sequence stratigraphic models (Posamentier et al., 1988). However, the most critical part of Oligocene to Holocene sequences are found beneath the modern continental shelf. Leg 174A will begin the task of shelf drilling with the JOIDES Resolution at outer shelf sites MAT8B (located near the COST B-2 well; Scholle, 1977) and MAT9B (located $3 \mathrm{~km}$ downdip of MAT8B; Fig. 1). The JOIDES Resolution cannot be used to drill the middle shelf Sites MAT4 through 7 or inner shelf Sites MAT 1 through 3 (Fig. 1); a supplementary platform (jack-up rig or semisubmersible) will be needed to complete this critical portion of the transect.

\section{PREVIOUS ONSHORE RECORDS}

The New Jersey Coastal Plain (Fig. 2) is the emergent part of a classic passive margin that formed following Triassic-Early Jurassic rifting (Grow and Sheridan, 1988). Post-rift tectonics have been dominated by simple thermal subsidence, sediment loading, and flexure (Watts and Steckler, 1979; Reynolds et al., 1991). Jurassic strata have not been identified in the coastal plain, although very thick Jurassic strata occur offshore in the Baltimore Canyon Trough. The coastal plain did not form until the Cretaceous, when the crust attained sufficient flexural rigidity for offshore thermal subsidence to cause accommodation onshore (Watts, 1982). The coastal plain consists of Lower Cretaceous to Holocene strata that dip gently $\left(<1^{\circ}\right)$ seaward and thicken downdip. The sediments are primarily unconsolidated siliciclastic sands and muds that were deposited in fluvial to shelfal environments, with a strong deltaic influence in the Cretaceous and in the Miocene to Holocene (Owens and Sohl, 1969; Owens and Gohn, 1985). Paleowater depths generally increased from the mid- to Late Cretaceous, attaining maximum water depths onshore in the early Eocene. A general regression occurred over the last 50 m.y. and upper Miocene-Holocene strata are primarily marginal marine to nonmarine. Cretaceous outcrops are exposed but weathered, whereas much of the Cenozoic record is derived from subsurface boreholes where strata are thicker and more marine.

New Jersey Coastal Plain siliciclastic strata have been studied since the early 1800's (e.g., Lyell, 1845). Owens and Sohl (1969) first recognized unconformity-bounded transgressive/regressive cycles in the coastal plain and attributed them to tectonic controls. Olsson and colleagues, using planktonic foraminifers and nannofossils to compare New Jersey Coastal Plain Sequences to the Haq et al. (1987) record, interpreted the transgressions and regressions in terms of global sea level (e.g., Olsson and Wise, 1987; Olsson et al., 1987; Olsson, 1991). Unfortunately, previous studies have been hampered by insufficient material for study (weathered outcrops and discontinuously sampled rotary wells and boreholes), and the roles of tectonics vs. eustasy remain debatable.

Lack of continuously sampled sections contributed to controversies about even the most basic stratigraphic interpretations. For example, the first identification of Oligocene strata in the New Jersey Coastal Plain by Olsson et al. (1980) was not accepted at first, and the lower to middle Miocene Kirkwood Formation was poorly calibrated to the time scale until the advent of Sr-isotopic stratigraphy (Sugarman et al., 1993). The USGS improved Tertiary stratigraphic correlations in New Jersey in 1986 by continuously coring the ACGS\#4, Mays Landing borehole, attaining excellent recovery (Fig. 2; Owens et al., 1988). Drilling of this and other continuous boreholes at Belleplain (Sugarman et al., 1993), Allaire (Sugarman et al., 1991), and Clayton (Gibson et al., 1993) provided material for integrated biostratigraphic (Poore and Bybell, 1988), Sr-isotopic (Sugarman et al., 1993; Miller et al., 1990), and magnetostratigraphic studies (Miller et al., 1990). The success of these initial drilling efforts led to planning of the New Jersey Coastal Plain drilling project. 


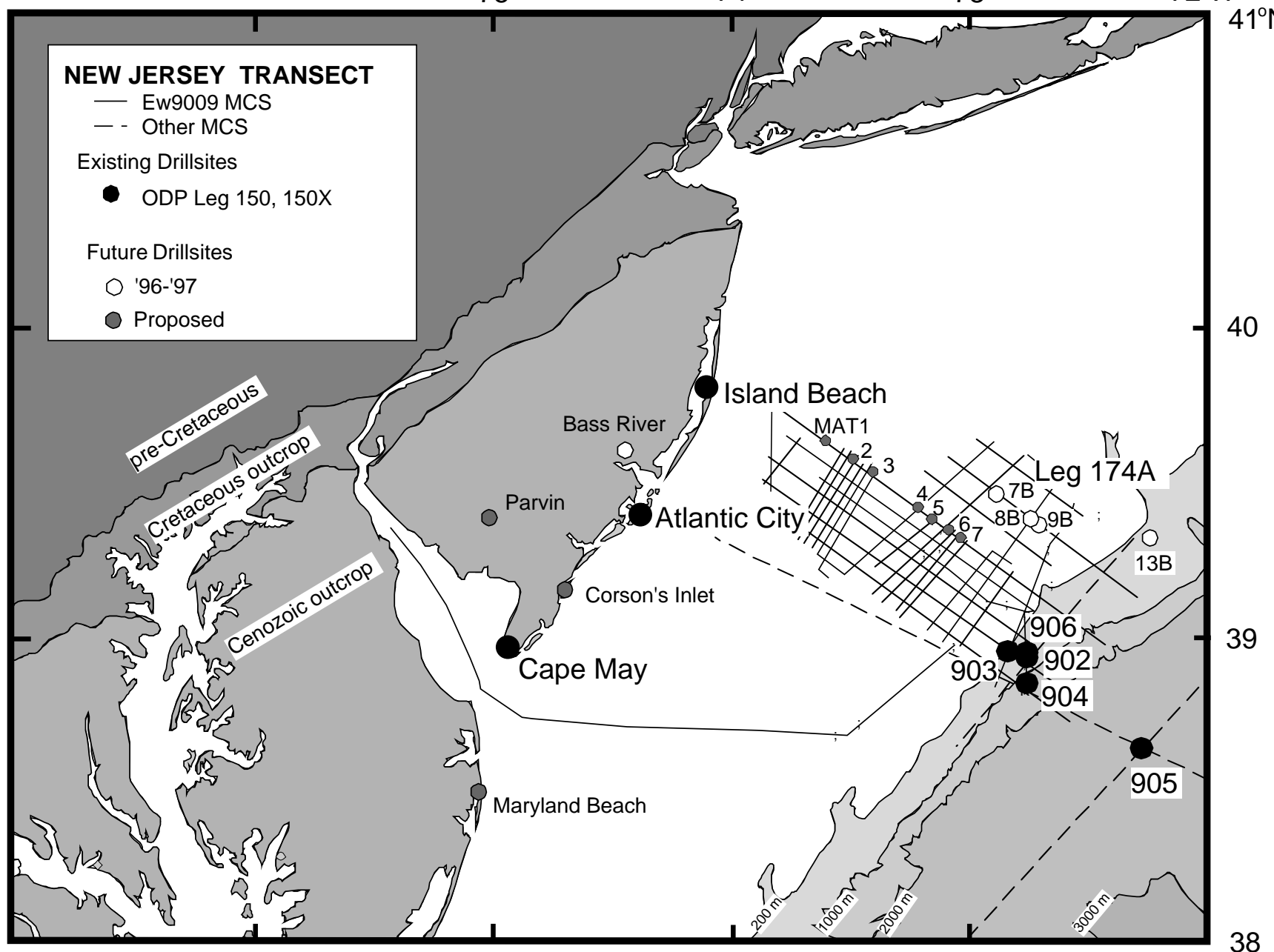

Figure 1. Location map of the Middle Atlantic Margin showing Leg 150X onshore and Leg 150 slope boreholes (solid circles), scheduled boreholes (open circles; Bass River and MAT8B and 9B), and proposed boreholes (shaded circles; MAT 1 through 7B on shelf), and the Ewing multichannel seismic grid.

\section{THE NEW JERSEY COASTAL PLAIN DRILLING PROJECT}

The onshore drilling program was sponsored by the National Science Foundation, Earth Science Division, Continental Dynamics and Ocean Drilling Programs. Drilling was a collaborative effort among Rutgers University, Lamont-Doherty Earth Observatory, the New Jersey Geological Survey, and the Branch of Eastern Regional Geology (BERG) of the USGS. The JOIDES planning committee endorsed the onshore drilling as an Ocean Drilling Program (ODP) related activity that was designated Leg 150X. Three boreholes were continuously cored by BERG drillers in 1993-1994 at Island Beach State Park, Atlantic City, and Cape May. The onshore sites were located as far downdip as possible to maximize the thickness (and minimize the number of hiatuses) of the upper Oligocene to middle Miocene section and to be close to offshore multichannel seismic ties (Fig. 1). The sites were chosen to maximize recovery of different portions of the section. The Cape May borehole recovered the most complete and thickest Miocene section due to its downdip location; boreholes to the north penetrated a thinner Neogene section and progressively older portions of the Paleogene.

The USGS BERG drillers used a Christensen core barrel to attain good recovery from the unconsolidated coastal plain strata. Recovery at Island Beach was outstanding (87\% mean, $96 \%$ median) and all contacts were recovered, except for the Cretaceous/Tertiary $(\mathrm{K} / \mathrm{T})$ boundary; a complete suite of slimline logs were obtained. Recovery at Atlantic City (60\% mean) was moderate because of difficult hole conditions, but was excellent in the most critical sections ( $81 \%$ in the lower-middle Miocene interval between 390 and $937 \mathrm{ft}$ [118.9 and $285.6 \mathrm{~m}]$ ). Good gamma and neutron logs were obtained. The Cape May borehole had good recovery (75\% mean, $85 \%$ median), gamma, and neutron logs.

At all three Leg 150X coastal plain boreholes, unconformities were identified on the basis of physical evidence (including irregular contacts, reworking, bioturbation, and major facies changes) and well-log (gamma-ray peaks) characteristics, and paraconformities were inferred from biostratigraphic and/or Sr-isotopic breaks. Recognition of these surfaces allows identification of sequences. For the nonmarine and near-shore sections (primarily the Miocene and younger section), lithofacies interpretations provide the primary means of interpreting paleoenvironments. For the neritic sections (primarily the Paleogene), benthic foraminiferal biofacies studies provide the primary means of interpreting paleoenvironments.

Facies changes within sequences (systems tracts) follow general patterns in the New Jersey Coastal Plain (Owens and Sohl, 1969; Owens and Gohn, 1985; Sugarman et al., 1993). Sequences onshore typically consist of a basal transgressive glauconite sand overlain by a coarsening-upward succession of regressive medial silts and upper quartz sands (Owens and Sohl, 1969). The basal glauconite sand (= condensed section of Loutit et al., 1988) is equivalent to the upper 


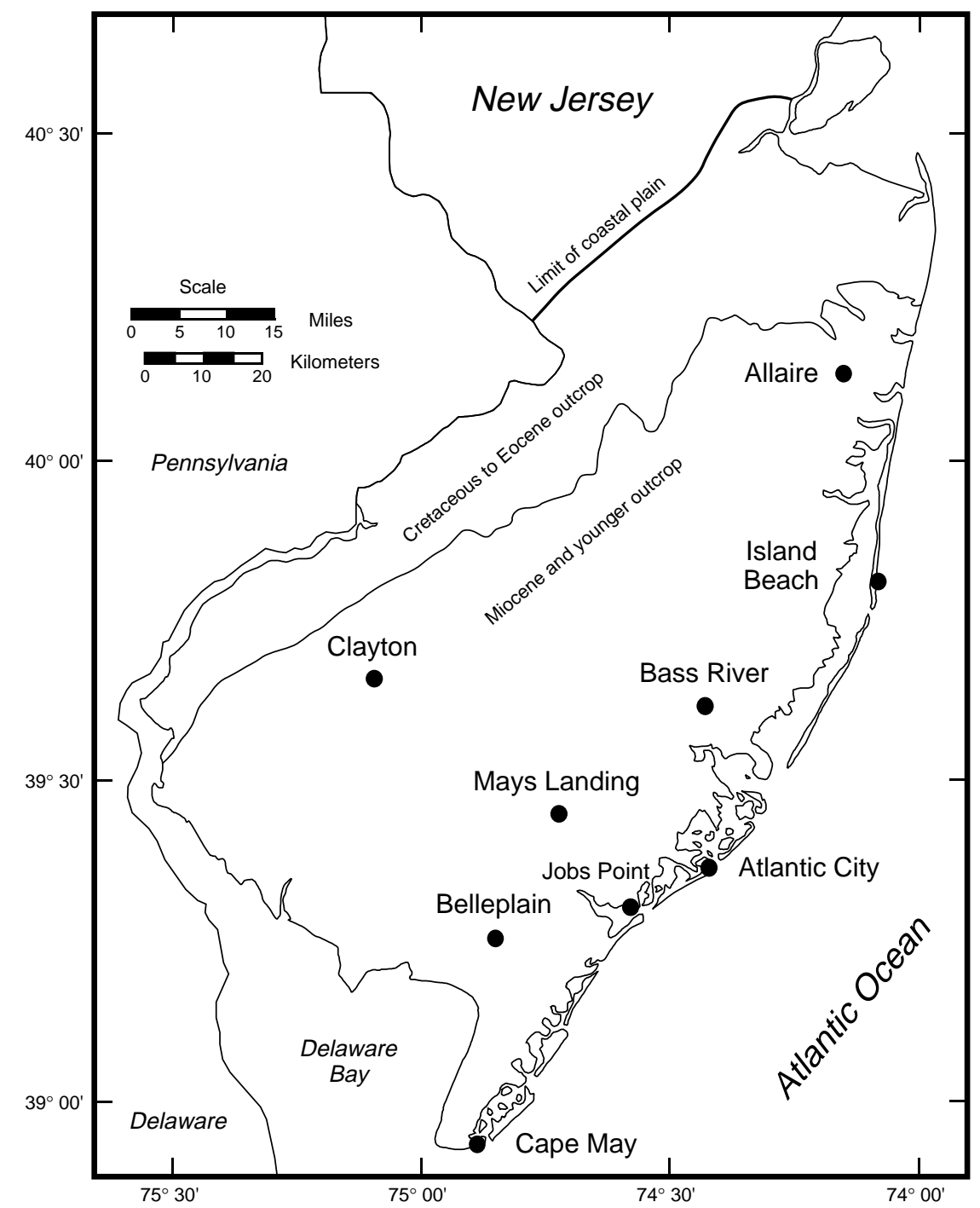

transgressive systems tract (TST) of Posamentier et al. (1988). The overlying medial silt is equivalent to the lower Highstand Systems Tract (HST), whereas the upper quartz sands represent the upper HST (Sugarman et al., 1993). This results in a distinct gamma-log signature with "hot" zones at the base and low values at the top (Sugarman et al., 1993).

The facies successions vary somewhat from the Cretaceous to Miocene, reflecting differences in paleodepth, provenance, and preservation (Fig. 4). Miocene sequences consist of clay confining units at the base with quartz sand aquifers at the top, deposited in inner to middle neritic environments (Sugarman et al., 1993; Miller, et al., 1994; Miller et al., Chapter 14, this volume). Oligocene sequences are similar (Fig. 4), although they represent deeper water (inner to outer neritic) environments; in addition, recycled glauconite occurs in Oligocene HSTs, obscuring the facies successions (Pekar and Miller, 1996; Pekar et al., Chapter 15, this volume). Expression of Eocene sequences is muted, reflecting deposition in the deepest paleodepths (middle to outer neritic; Browning et al., Chapter 17, this volume). Cretaceous sequences show distinct changes from basal glauconite, medial silts, and upper sands (Sugarman et al., 1995b).

Because of local tectonic differences, not all sequences are represented at each site. The oblique-strike orientation of the three Leg 150X boreholes allows sampling of a different set of sequences at each location. For example, middle Miocene and younger sequences are deeper water and more complete in the southern part of New Jersey, attaining progressively deeper paleodepths toward the depocenter at Salisbury, Maryland (Owens and Gohn, 1985). Lower Miocene sequences are best expressed at Cape May and Atlantic City (Miller et al., Chapter 14, this volume), whereas mid-upper Oligocene sequences are best represented at Atlantic City. By sampling at multiple locations, the New Jersey Coastal Plain Drilling Project was successful in assembling a mosaic of coastal plain sequences that record latest Cretaceous to Holocene relative sea-level changes.

\section{Island Beach}

The Island Beach borehole is located directly updip of proposed offshore shelf Sites MAT1-3 and a multichannel seismic grid collected by the R/V Maurice Ewing in 1990 (Miller and Mountain, 1994; Figs. 1, 2). This site recovered Oligocene to lower Miocene ("Icehouse") sequences and is the only borehole drilled by Leg 150X that fully addresses Paleocene to Eocene ("Doubthouse") sequences. Although the Paleogene succession at Island Beach contains most nannofossil (NP3, NP5, NP6, NP9 though NP22, NP24-25) and planktonic foraminiferal (P1c though P6a, P6c through P21a) zones, deposition was punctuated by numerous disconformities (Miller, et al., 1994). The excellent recovery, well-developed facies, detailed Paleogene biostratigraphy, Sr-isotope stratigraphy, and magnetostratigra- 


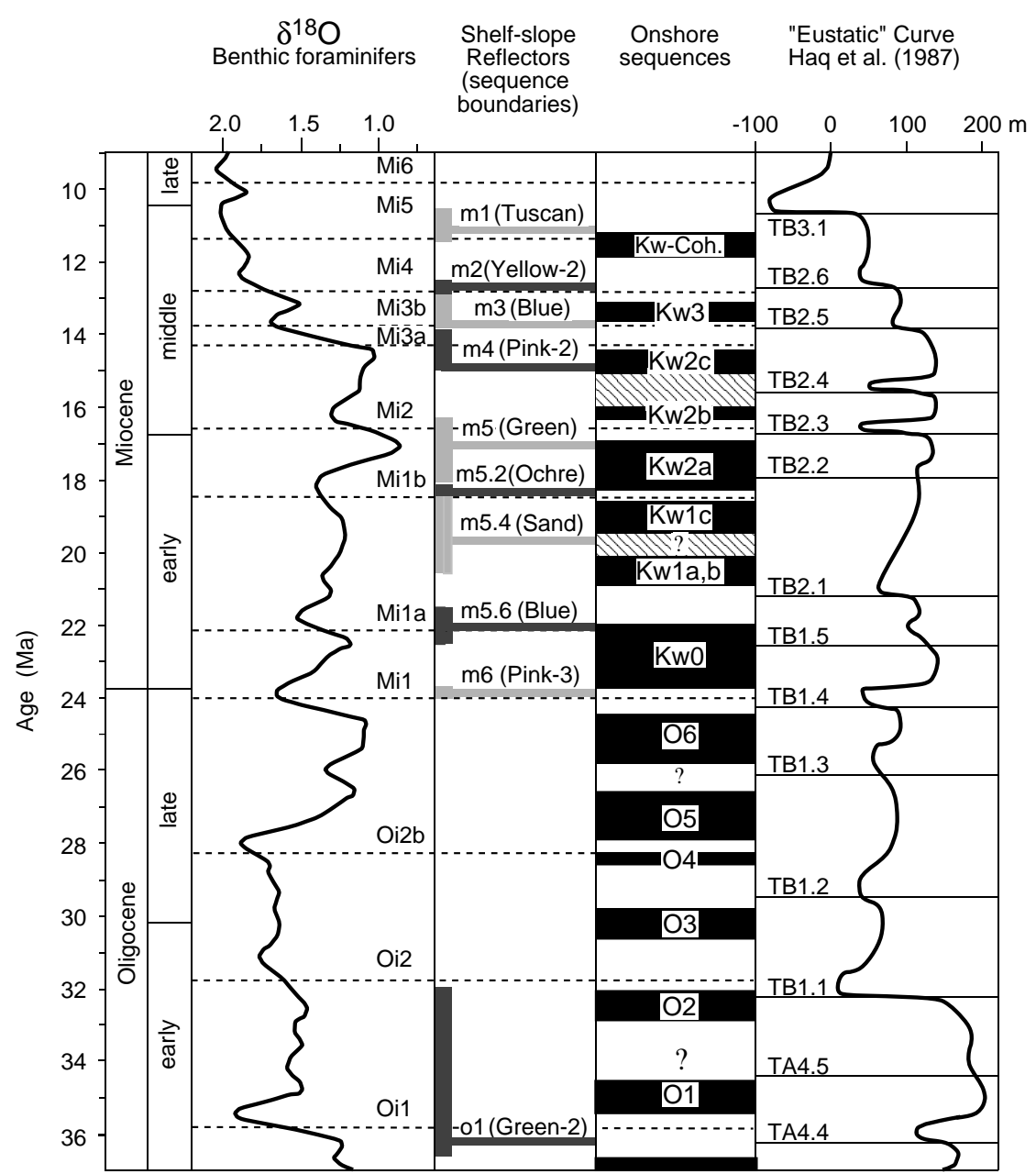

Figure 3. Comparison of the timing of Oligocene to late Miocene reflectors on the New Jersey slope with a stacked benthic foraminiferal $\delta^{18} \mathrm{O}$ record, a summary of onshore sequences, and the inferred eustatic record of Haq et al. (1987). The $\delta^{18} \mathrm{O}$ is a stacked record of Cibicidoides spp. from several sites that has been smoothed to remove all periods longer than $\sim 1$ m.y. Oi1 to Mi6 are $\delta^{18} \mathrm{O}$ maxima; dashed lines indicate inflections in the $\delta^{18} \mathrm{O}$ records. O1 to $\mathrm{m} 1$ are reflectors dated on the New Jersey slope and are shown with best-age estimates indicated with thin lines and error bars indicated with boxes. Onshore sequences are indicated by dark boxes; white areas in between are hiatuses. O1 to $\mathrm{O} 6$ are Oligocene and $\mathrm{Kw} 0$ to $\mathrm{Kw}-\mathrm{Coh}$. are Miocene onshore New Jersey sequences; cross-hatched areas indicate uncertain ages. TA4.4 to TB3.1 are sequences of Haq et al. (1987) and are drawn at the inflection points in their inferred eustatic record. Time scale is that of Berggren et al. (1985). Figure is after Miller et al. (1996c). phy at Island Beach allowed dating of Cenozoic sequences and evaluation of vertical facies succession within sequences.

\section{Surficial Units}

The Cape May Formation at Island Beach consists of unconsolidated sands, silts, clays, and gravels containing lignite and shell layers that are dated by radiocarbon accelerator mass spectrometer (AMS) as Holocene (younger than $6 \mathrm{ka}$ Fig. 5, back pocket, this volume). The sequence is a deepening upward succession of fluvial, bayestuarine, and near-shore facies that records the Holocene transgression (Miller, et al., 1994).

\section{Miocene Kirkwood Formation}

Owens et al. (1995) recently redefined the Kirkwood Formation, previously recognized as the lower to middle Miocene sands and clays in New Jersey (Sugarman et al., 1993), recognizing four formations increasing in age: Belleplain, Wildwood, Shiloh Marl, and Kirkwood. These are equivalent to the Kirkwood 3, Kirkwood 2a and 2b, Kirkwood 1b, and Kirkwood 1a and Kirkwood 0, respectively, of Sugarman et al. (1993), Miller and Sugarman (1995), and this report. In this paper, we retain the older use of the Kirkwood Formation and applied Owens et al.'s (1995) terminology as members of the Kirkwood Formation (see justification in Miller et al., Chapter 14, this volume; Fig. 2). Miller et al. (Chapter 14, this volume) name the most widespread unit the Brigantine Member, which corresponds to the
Kw1a sequence and the Kirkwood Formation in the restricted sense of Owens et al. (1995; Fig. 5).

The 130-m-thick (427 ft) Kirkwood Formation at Island Beach consists of successions of unconsolidated silty clay overlain by sands. The facies represent diverse fluvial, near-shore, and inner neritic (including prodelta) environments. Diatoms were used to correlate the Kirkwood Formation at Island Beach to lowermost middle to lower Miocene, whereas Sr isotopes were used to date the lowermost Kirkwood Formation recovered here as $21.8 \mathrm{Ma}$ (early Miocene; Miller, et al., 1994). Other age constraints are lacking for the Kirkwood Formation at Island Beach because of shallow-water and nonmarine facies; however, the lithostratigraphic subdivisions at Island Beach can be correlated to the Atlantic City borehole, where they are dated using Sr-isotopic stratigraphy (Sugarman and Miller, 1997). These correlations allow evaluation of lateral facies changes in at least three Miocene sequences, the Kirkwood 1a, Kirkwood 1b, and Kirkwood 2a (Sugarman and Miller, 1997), corresponding to the Brigantine, Shiloh Marl, and Wildwood Members, respectively.

\section{Upper Oligocene Atlantic City Formation}

The upper Oligocene Atlantic City Formation of Pekar et al. (Chapter 8, this volume) at Island Beach consists of medium to coarse glauconitic quartz sands that grade downward into slightly clayey medium glauconite sand with occasional glauconite sandy clay (Fig. 5; Miller, et al., 1994). Biostratigraphic control on this section is poor. By integrating biostratigraphy, $\mathrm{Sr}$-isotopic stratigraphy, mag- 


\section{New Jersey Sequences}

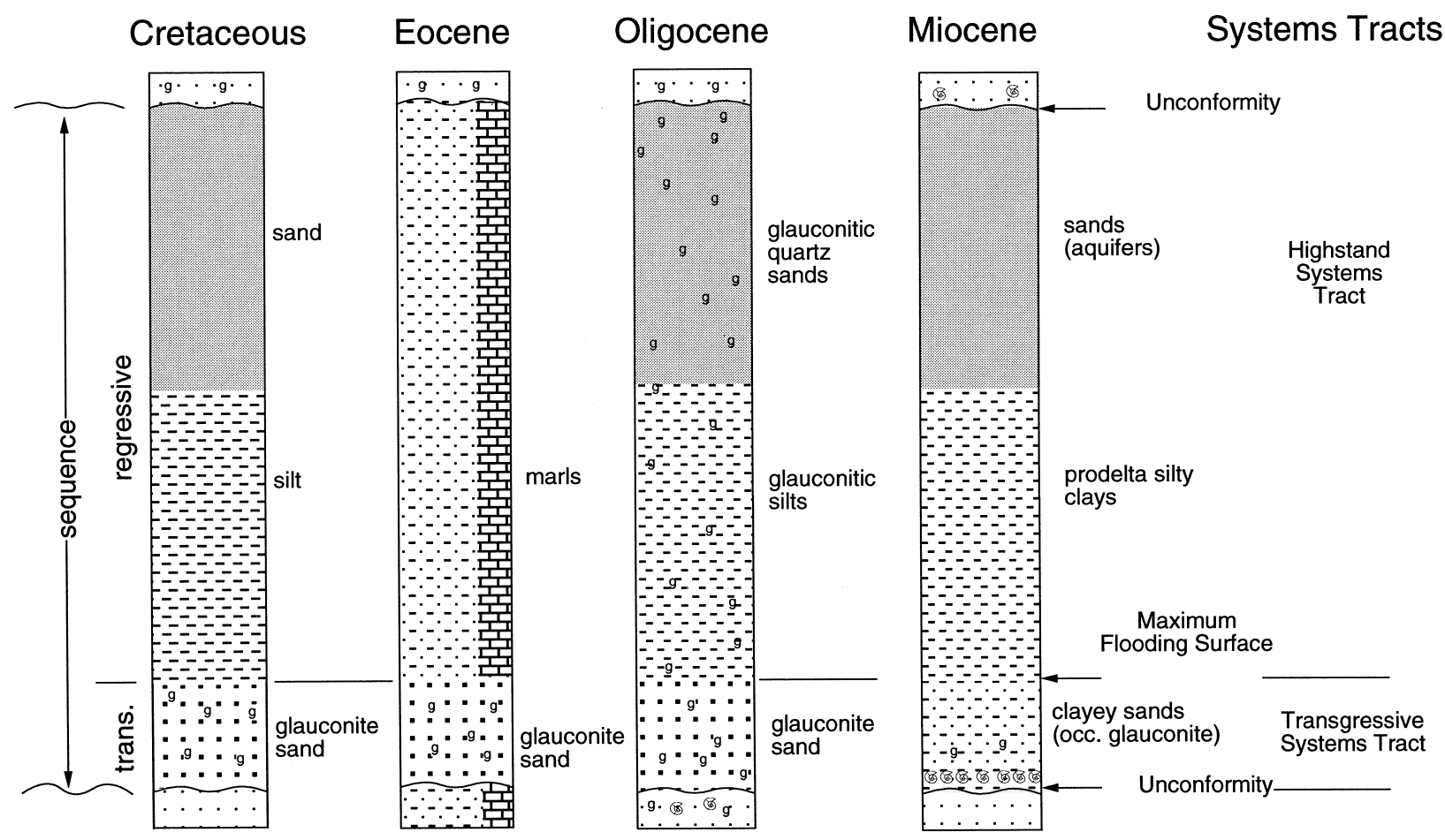

Figure 4. Generalized models of New Jersey sequences showing the upsection shallowing common to different facies successions of the Cretaceous, Eocene, Oligocene, and Miocene. The equivalent Systems Tracts of Posamentier et al. (1988) are shown on the right. Glauconite in the Oligocene HST is reworked. Trans. $=$ transgressive, occ. $=$ occasional.

netostratigraphy, and well-log correlations, Pekar and Miller (1996) recognize at least one sequence at this site (O6?); this sequence is assigned to planktonic foraminiferal Zone P22 at other Leg 150X sites.

\section{Oligocene Sewell Point Formation}

At Island Beach, the Sewell Point Formation of Pekar et al. (Chapter 8, this volume) consists of medium glauconite sand (Fig. 5; Miller, et al., 1994). It has been divided into two sequences (O2 and O1) correlated to Zone P19-20 and P18, respectively (Pekar and Miller, 1996; Pekar et al., Chapter 15, this volume). This formation is entirely lower Oligocene at Island Beach, although the formation includes upper Oligocene strata at other Leg 150X sites.

\section{Eocene Absecon Inlet, Shark River, and Manasquan Formations}

Excellent recovery, well-preserved and diverse microfossils, well logs obtained on formation, and magnetostratigraphy at Island Beach provide one of the best-dated records of Eocene sequences (Fig. 5):

1. The upper Eocene Absecon Inlet Formation (Browning et al., Chapter 18, this volume) and upper (?) to middle Eocene section consist of occasionally pebbly glauconitic sandy clay and clayey glauconite sand deposited in middle neritic $(30-100 \mathrm{~m})$ paleodepths. Sequences occur from 697 to $710 \mathrm{ft}(212.4-216.4$ $\mathrm{m})$ and 710 to $750 \mathrm{ft}(216.4-228.6 \mathrm{~m})$.

2. The middle to lower upper Eocene Shark River Formation consists of sandy clay, glauconite sandy clays/clayey sands, and clayey sand deposited in middle-outer neritic paleodepths (30-150 m). A sequence from 750 to $779 \mathrm{ft}(228.6-237.4 \mathrm{~m})$ contains coarse sand and extensive biostratigraphic reworking (Browning et al., 1996; Browning et al., Chapter 16, this volume); it was originally grouped with other upper Eocene strata (Miller, et al., 1994), although subsequent studies identify it as the Toms River Member of the Shark River Formation. Below this, the Shark River Formation may be broken into sequences by unconformities at $800 \mathrm{ft}(243.8 \mathrm{~m}), 846 \mathrm{ft}(257.9 \mathrm{~m})$, and $857 \mathrm{ft}$ ( $261.2 \mathrm{~m}$; at the probable lower/middle Eocene boundary). The boundary with the underlying Manasquan Formation is either at 857 or $862 \mathrm{ft}(262.7 \mathrm{~m})$, the level of another disconformity (Browning et al., 1996; Browning et al., Chapter 17, this volume).

3. The thick (213 ft [64.9 m]) lower Eocene Manasquan Formation consists of clay, sandy clay, and porcellanitic clays (Fig. 5 ). It provides a record of the deepest water (primarily outer neritic; $100-200 \mathrm{~m}$ paleodepth) environments attained in the New Jersey Coastal Plain. Integrated magnetostratigraphy, biostratigraphy, and benthic foraminiferal biofacies studies reveal that the Manasquan Formation may be broken into at least four sequences (E1-E4; Fig. 5; Browning et al., 1996; Browning et al., Chapter 17, this volume). In addition, the deeper paleodepths allowed generation of a stable isotopic record spanning the upper Paleocene into the lower Eocene (Pak et al., Chapter 23, this volume).

\section{Paleocene Vincentown Formation and Hornerstown Equivalent}

The upper Paleocene Vincentown Formation contains cyclic laminations of clays and silts deposited in neritic environments (Fig. 5). It represents at least two depositional sequences correlated with Zones NP8-9 and NP5-6, respectively (Miller, et al., 1994). 
A lower Paleocene sequence is represented by the downdip equivalent of the Hornerstown Formation; it records laminated silts (Zones NP3, P1c) of the HST that are not preserved updip. The K/T contact was not recovered. The Maastrichtian glauconite sandy clay to clayey sands are assigned to the undifferentiated Red Bank/Navesink Formations (Miller, et al., 1994).

\section{Atlantic City}

The Atlantic City site was the second borehole drilled as part of the New Jersey Coastal Plain drilling project. It focused on middle Miocene to Oligocene "Icehouse" and middle-upper Eocene "Doubthouse" sequences. Lower and middle Miocene sequences are well expressed and dated at this site. Middle and upper Oligocene sequences are the best preserved of the three Leg 150X boreholes. The presence of mid-Oligocene strata at Atlantic City and its absence downdip at Cape May are attributed to minor differences in subsidence histories between locations (Miller, et al., 1994).

\section{Surficial Units}

The section from 12 to $53 \mathrm{ft}(3.7-16.2 \mathrm{~m})$ was deposited in nearshore/estuarine environments and is correlated with the upper(?) Pleistocene to Holocene Cape May Formation (Fig. 5). The stratigraphic interpretation of the section between 53 and $388 \mathrm{ft}$ (16.2 and $118.3 \mathrm{~m}$ ) at this site is uncertain because of poor fossil control (the strata are nonmarine; Miller, et al., 1994) and no recovery from 293$388 \mathrm{ft}(89.3-118.3 \mathrm{~m})$. Miller, et al. (1994) interpreted the upper 135 $\mathrm{ft}(41.1 \mathrm{~m})$ of the borehole to represent the Pleistocene to Holocene Cape May Formation, the interval from 135 to $223 \mathrm{ft}(41.1-68.0 \mathrm{~m})$ as the middle (?) Miocene Cohansey Formation, and the interval below this to $293 \mathrm{ft}(89.3 \mathrm{~m})$ as the Kirkwood Formation (Fig. 5). In contrast, Owens et al. (1995) interpreted the interval from 53 to 293 $\mathrm{ft}(16.2-89.3 \mathrm{~m})$ as the Cohansey Formation based on regional mapping, which indicates that the Cohansey Formation was deeply channeled at this location.

\section{Miocene Kirkwood Formation}

Recovery of the uppermost part of the 706-ft-thick (215.2 m) lower to middle Miocene Kirkwood Formation was poor, but recovery for the Kirkwood Formation between 390 and $937 \mathrm{ft}$ (118.9 and 285.6 $\mathrm{m})$ was excellent. The sand, silt, and clay facies in the Kirkwood Formation at Atlantic City represent diverse fluvial, near-shore, and neritic (including prodelta) environments (Miller, et al., 1994). Facies interpretations of the Kirkwood Formation at Atlantic City are presented by Sugarman and Miller (1997) and Miller et al. (Chapter 14, this volume). Several coarsening-upward sequences can be recognized on the basis of lithofacies breaks, gamma log changes, and hiatuses. These sequences correspond to confining silty clays at the base and aquifer sands at the top. We recovered thick shell beds in the lower to middle Miocene Kirkwood Formation that yielded Srisotope ages of these Miocene sequences (Miller, et al., 1994; Miller and Sugarman, 1995; Sugarman et al., Chapter 12, this volume). The shell beds are similar to the "Calvert Cliffs" of Maryland, although our studies show them to be thicker and more continuous than those in the Maryland sections (Miller and Sugarman, 1995); in addition, the interval from 25 to $18 \mathrm{Ma}$ that is not represented in Maryland is well represented at Atlantic City (Fig. 5).

\section{Upper Oligocene Atlantic City Formation}

The upper Oligocene section at Atlantic City is used to stratotypify the upper Oligocene Atlantic City Formation (Fig. 5; Pekar et al., Chapter 8, this volume). It is comprised of dominant glauconitic quartz sands with subordinate glauconite sands (Miller, et al., 1994).
Two sequences (O5 and O6, both correlated with Zone P22; Pekar and Miller, 1996; Pekar et al., Chapter 15, this volume) are recognized in the upper Oligocene at this site. The boundary with the underlying Sewell Point Formation was not recovered, and the lower part of Sequence O5 is tentatively placed in the lower formation.

\section{Oligocene Sewell Point Formation}

The Oligocene Sewell Point Formation of Pekar et al. (Chapter 8, this volume) at Atlantic City is comprised of glauconite sands and glauconitic silts, lacking the quartz sand of the overlying formation (Fig. 5; Miller, et al., 1994). The Oligocene section thus coarsens upsection at this site. Three sequences $(\mathrm{O} 2, \mathrm{O} 3$, and $\mathrm{O} 4$ correlated with Zones P19-20 and P21a-b, and P21b, respectively; Pekar and Miller, 1996; Pekar et al., Chapter 15, this volume) are recognized in the Sewell Point Formation at Atlantic City.

\section{Upper Eocene Absecon Inlet Formation}

The upper Eocene Absecon Inlet Formation is stratotypified at Atlantic City (Browning et al., Chapter 18, this volume), where it is comprised of uniform dark gray silty clay representing one sequence (Fig. 5).

\section{Middle Eocene Shark River Formation}

The Shark River Formation at Atlantic City consists of three lithostratigraphic units (Fig. 5):

1. Uniform clays with subordinate glauconite sands contain mixed biostratigraphic markers. This unit (Sequence E9 of Browning et al., Chapter 17, this volume) may correlate with the Exmore Boulder Bed of Poag et al. (1992) and may reflect the influence of an impact event(s).

2. Uniform glauconitic sandy clay is assigned to Sequence E8 of Browning et al. (Chapter 17, this volume).

3. Carbonate clay to clayey chalk is assigned to Sequence E7 of Browning et al. (Chapter 17, this volume).

\section{Cape May}

The Cape May borehole recovered the most complete, thickest, and most reliably dated Miocene section because of its basinal (downdip) position. The lower Oligocene is best represented at this borehole, although upper Oligocene strata are better represented at Atlantic City. Facies changes within uppermost Oligocene to middle Miocene sequences (systems tracts) are distinct. The bases of the sequences contain shell beds (typically $1-2 \mathrm{ft}[0.3-0.6 \mathrm{~m}]$ thick) that grade upward to clays/silts (typically 15-90 $\mathrm{ft}$ [4.6-27.4 m] thick) and sands (typically $40-120 \mathrm{ft}[12.2-36.6 \mathrm{~m}]$ thick). Capping the Miocene sequences are indurated zones that may reflect subaerial exposure. A major change in depositional regime from shelfal to deltaic domination occurred at Cape May between 22 and 21 Ma.

\section{Surficial Units}

The upper part of the borehole $(0-357 \mathrm{ft}[0-108.8 \mathrm{~m}])$ is poorly dated, because it represents fluvial-estuarine and marginal marine environments (Fig. 5; Miller, et al., 1996a). The upper (?) Pleistocene to Holocene Cape May Formation (0-75 ft; 0-23 m) consists of alternating organic-rich clays and shelly sands deposited in an inlet-marsh environment (Miller, et al., 1996a). Lower Pleistocene inlet sands $(75-90 \mathrm{ft}$ [22.9-27.4 m]) and underlying lower estuarine clays (90$140 \mathrm{ft}[27.4-42.7 \mathrm{~m}])$ are tentatively assigned to the Cape May Formation (Fig. 5; Miller, et al., 1996a). Thick (140-357 ft [42.7-108.8 $\mathrm{m}]$ ), poorly fossiliferous estuarine sands and clays were thought to be 
Pliocene based on stratigraphic correlation (Miller, et al., 1996a), although dinocyst studies (de Verteuil, Chapter 11, this volume) indicate that they are probably upper Miocene. Dinocysts also indicate that the section from 90 to $140 \mathrm{ft}(27.4-42.7 \mathrm{~m})$ is Miocene.

\section{Miocene Kirkwood Formation}

As at the other sites, the Kirkwood Formation consists of successions of unconsolidated silty clay and sands (Fig. 5). Four middle Miocene sequences representing $258 \mathrm{ft}(78.6 \mathrm{~m})$ were recovered, including the Kirkwood-Cohansey sequence ( 11-12 Ma; the youngest fossiliferous middle Miocene sequence sampled in New Jersey), the Kirkwood 3 sequence (13.1-13.7 Ma as dated at Atlantic City; Miller, et al., 1994), a previously unknown sequence (Kw2c; Fig. 5; 14.3-14.8 Ma), and the Kirkwood 2b sequence (15.9-16.3 Ma; Miller, et al., 1996a; Miller and Sugarman, 1995).

The thick lower Miocene section $(565 \mathrm{ft} ; 172.2 \mathrm{~m})$ represents at least five well-developed sequences (Miller, et al., 1996a; Miller and Sugarman, 1995).

1. The Kirkwood 2a sequence (650-715 ft [198.1-217.9 m]; 17.0-18.1 Ma as dated at Atlantic City; Miller and Sugarman, 1995) is a classic coarsening-upward sequence with basal shelly, sandy silts and clays (shelf environments); medial micaceous, carbonaceous, laminated clay-silts and fine sands (prodelta environments); and upper interbedded sands and carbonaceous silts (delta front environments).

2. A thick $(710-850 \mathrm{ft}[216.4-259.1 \mathrm{~m}])$ sequence, which is 18.6 to $19.5 \mathrm{Ma}$ (Kw1c; Fig. 5), was not previously identified elsewhere in New Jersey.

3. Kirkwood 1b (850-942 ft [259.1-287.1 m]; 20.1 Ma) is a coarsening-upward sequence of basal clays and upper sands.

4. Kirkwood 1a (942-1062 ft [287.1-323.7 m]; 20.4-20.9 Ma) is a coarsening-upward sequence separated from Kirkwood $1 \mathrm{~b}$ by a major disconformity indicated by gamma logs, facies shifts, and an irregular surface at the contact, although there is no discernible hiatus between these sequences.

5. The lowermost Miocene ( 23.1-22.7 Ma) Kirkwood 0 sequence consists of neritic glauconite sands.

\section{Upper Oligocene Atlantic City Formation}

At Cape May, the upper Oligocene Atlantic City Formation of Pekar et al. (Chapter 8 , this volume) consists of interbedded laminated clays, glauconitic quartz sands and sandy clay, and clayey quartzose glauconite sands (Fig. 5; Miller, et al., 1996a). This formation comprises the upper part of Sequence O6, correlated with Zone P22; Pekar and Miller, 1996; Pekar et al., Chapter 15, this volume).

\section{Oligocene Sewell Point Formation}

The Oligocene Sewell Point Formation is stratotypified at Cape May (Pekar et al., Chapter 8, this volume), where it consists of clayey, silty fine-grained glauconite sands and sandy clays (Fig. 5). Pekar and Miller (1996) and Pekar et al. (Chapter 15, this volume) recognize three lower $(\mathrm{O} 1, \mathrm{O} 2$, and $\mathrm{O} 3)$ and two upper $(\mathrm{O} 5$ and $\mathrm{O} 6$ partim) Oligocene sequences in the Sewell Point Formation at this site. The lower Oligocene unconformably overlies the upper Eocene.

\section{Upper Eocene Absecon Inlet Formation}

The upper Eocene at Cape May comprises uniform, neritic clays (Zone P15-P17; Miller, et al., 1994). Browning et al. (Chapter 18, this volume) were able to recognize two sequences, E10 and E11, within the upper Eocene Absecon Inlet Formation at Cape May.

\section{COMPARISON OF ONSHORE AND OFFSHORE STUDIES}

Sequence geometries are most clearly developed in the Oligocene-Holocene sequences beneath the modern New Jersey continental shelf (Greenlee et al., 1988, 1992; Miller and Mountain, 1994); onshore sequences represent only the updip part of these sequences. Boundaries between sequences beneath the modern New Jersey shelf were identified by seismic reflector terminations, traced to the slope, and dated at Sites 902-904 and 906 (Fig. 1). Consequently, the slope sites can be used to date these shelf sequences. Similarly, the coastal plain boreholes have been used to date coeval sequences; however, no direct seismic ties are available at present for Island Beach, Atlantic City, or Cape May.

The first step in both onshore and offshore studies has been to develop a detailed chronology of sequences. Oligocene to middle Miocene chronologic control for the Leg 150 slope boreholes is provided by integrating Sr-isotopic stratigraphy (Miller et al., 1996b) and magnetostratigraphy (Van Fossen and Urbat, 1996) with planktonic foraminiferal (Snyder et al., 1996), nannofossil (Aubry, 1996), dinocyst (de Verteuil, 1996), and diatom (Burckle, 1996) biostratigraphy (see synthesis in Miller et al., 1996c). Similarly, onshore chronologic control for the Oligocene to middle Miocene is provided by integrating Sr-isotopic stratigraphy (Miocene, Sugarman et al., Chapter 12, this volume; Oligocene, Pekar et al., Chapter 15 , this volume) and magnetostratigraphy (Van Fossen, Chapter 22, this volume) with foraminiferal (Liu et al., Chapter 10, this volume), nannofossil (M.-P. Aubry in Miller, et al., 1994, 1996a), dinocyst (de Verteuil, Chapter 11 , this volume), and diatom (Burckle, Chapter 13, this volume) biostratigraphy. Onshore Eocene chronology is addressed by Browning et al. (Chapters 17 and 18 , this volume).

Our chronology of Oligocene to middle Miocene onshore and slope sequences shows that the unconformities correlate well with major $\delta^{18} \mathrm{O}$ increases, confirming that these sequence boundaries were formed during global sea-level lowerings (Fig. 3; Miller et al., 1996b). Comparison of onshore and offshore sequences with those of Haq et al. (1987) shows that Oligocene to middle Miocene Exxon sequences are recorded on the New Jersey Margin where their ages are well constrained (Fig. 3; Miller et al., 1996b).

The second step in onshore studies has been to develop a sequence stratigraphic framework for different parts of the Cenozoic by integrating chronologic, lithostratigraphic, well log, core log, benthic foraminiferal biofacies, and isotopic studies. These studies include evaluation of unconformities and flooding surfaces, delineating systems tract variations within sequences, and estimating water depth variations within sequences. Miocene sequence stratigraphic frameworks are presented by Sugarman et al. (Chapter 12, this volume), Miller et al. (Chapter 14, this volume), Miller and Sugarman (1995), and Sugarman and Miller (1997), and the Oligocene framework is developed by Pekar and Miller (1996) and Pekar et al. (Chapter 15, this volume). Browning et al. (Chapter 17, this volume) and Browning et al. (Chapter 18, this volume) provide an integrated framework for the Eocene of the New Jersey Coastal Plain including the Leg 150X boreholes, the Allaire borehole, and the ACGS\#4 borehole. Liu et al. (Chapter 19, this volume) evaluate the Paleocene sequences at Island Beach. The final goal of these studies is to produce a Cenozoic relative sea-level record of the New Jersey Coastal Plain by applying modeling techniques to the empirical record of sequences and water depth changes.

The onshore boreholes have provided a wealth of material for other investigations. These range from evaluations of clay mineralogy (Vanderaveroet and Deconinck, Chapter 4, this volume; Van Valkenburg et al., Chapter 5, this volume), silica diagenesis (McHugh, Chapter 3, this volume), core log/well log integration (Metzger et al., Chapter 6, this volume), additional paleontological studies (Bybell 
and Self-Trail, Chapter 9, this volume; Gohn, Chapter 21, this volume), palynology and climate (Sugarman et al., 1995a), pore-water quality (Pucci et al., Chapter 24, this volume), and pore-water isotopic composition (Szabo et al., Chapter 25, this volume).

Although we have been successful in both coastal plain and slope drilling, we note that the shelf must be drilled to evaluate the full range of facies variations within sequences, to develop the database needed to estimate relative sea-level changes, and to evaluate fully the response of margin sedimentation to sea-level changes. Leg 174A will begin these efforts by drilling two sites on the outer continental shelf. However, only by drilling on the inner and middle shelf (Sites MAT1 through 7; Fig. 1) can the full range of facies be sampled and the New Jersey Transect completed.

\section{ACKNOWLEDGMENTS}

I thank the members of the New Jersey Coastal Plain Drilling Project for fulfilling the promise of onshore drilling, G. Mountain and N. Christie-Blick for collaboration in planning the New Jersey sea level transect, and W. Newell and the late J. Owens (both USGS) for support and guidance of our efforts. The USGS BERG drillers did an outstanding job in obtaining the cores. The New Jersey Geological Survey supplied materials, personnel, and logging support. Rutgers University provided space for interim core storage and core analyses, field vehicles, and materials. R.K. Olsson (Rutgers) supplied unpublished data from other onshore wells and advice on planktonic foraminiferal studies. The National Science Foundation Continental Dynamic Program (L. Johnson, Program Director) and Ocean Drilling Program (B. Malfait, Program Director) co-funded the onshore boreholes (Leg 150X) and, along with PCOM and ODP, are to be commended for their flexibility and vision in authorizing Leg $150 \mathrm{X}$ as an ODP activity. The publications staff at ODP was supportive throughout production of this and other Leg 150X volumes. Discussions with and reviews by J. Browning, M. Katz, T. Loutit, S. Pekar, R. Olsson, D. Sahagian, S. Snyder, and P. Sugarman are greatly appreciated. Supported by NSF Grants EAR92-18210 and EAR94-17108. This is LDEO contribution 5687.

\section{REFERENCES}

Aubry, M.-P., 1996. Data Report: Eocene to upper Miocene calcareous nannofossil stratigraphy. In Mountain, G.S., Miller, K.G., Blum, P., Poag, C.W., and Twichell, D.C. (Eds.), Proc. ODP, Sci. Results, 150: College Station, TX (Ocean Drilling Program), 435-437.

Berggren, W.A., Kent, D.V., Flynn, J.J. and van Couvering, J.A., 1985. Cenozoic geochronology. Geol. Soc. Am. Bull., 96:1407-1418.

Berggren, W.A., Kent, D.V., Swisher, C.C., III, and Aubry, M.-P., 1995. A revised Cenozoic geochronology and chronostratigraphy. In Berggren, W.A., Kent, D.V., Aubry, M.-P., and Hardenbol, J. (Eds.), Geochronology, Time Scales and Global Stratigraphic Correlation. Spec. Publ.Soc. Econ. Paleontol. Mineral., 54:129-212.

Browning, J.V., Miller, K.G., and Pak, D., 1996. Global implications of Eocene Greenhouse and Doubthouse sequences on the New Jersey Coastal Plain - The Icehouse cometh. Geology, 24:639-642.

Burckle, L.H., 1996. Diatom biostratigraphy, Leg 150. In Mountain, G.S., Miller, K.G., Blum, P., Poag, C.W., and Twichell, D.C. (Eds.), Proc. ODP, Sci. Results, 150: College Station, TX (Ocean Drilling Program) 17-35.

Christie-Blick, N., Mountain, G.S., and Miller, K.G., 1990. Stratigraphic and seismic stratigraphic record of sea-level change. In Sea-level Change: Washington (National Academy Press), 116-140.

de Verteuil, L., 1996. Data report: Upper Cenozoic dinoflagellate cysts from the continental slope and rise off New Jersey. In Mountain, G.S., Miller, K.G., Blum, P., Poag, C.W., and Twichell, D.C. (Eds.), Proc. ODP, Sci. Results, 150: College Station, TX (Ocean Drilling Program), 439-454.

Fairbridge, R.W., 1961. Eustatic changes in sea level. In Ahrens, L.H., Press, F., Rankama, K., and Rucorn, S.K. (Eds.), Physics and Chemistry of the Earth: London (Pergamon Press), 4:99-185.
Gibson, T.G., Bybell, L.M., and Owens, J.P., 1993. Latest Paleocene lithologic and biotic events in neritic deposits of southwestern New Jersey. Paleoceanography, 8:495-514.

Grabau, A.W., 1936. Oscillation of pulsation. Rep. Intern. Geol. Congress, XVI, 1:539-553.

Greenlee, S.M., Devlin, W.J., Miller, K.G., Mountain, G.S., and Flemings, P.B., 1992. Integrated sequence stratigraphy of Neogene deposits, New Jersey continental shelf and slope: comparison with the Exxon model. Geol. Soc. Am. Bull., 104:1403-1411.

Greenlee, S.M., and Moore, T.C., 1988. Recognition and interpretation of depositional sequences and calculation of sea level changes from stratigraphic data-offshore New Jersey and Alabama Tertiary. In Wilgus, C.K., Posamentier, H., Ross, C.A., and Kendall, C.G.St.C. (Eds.), SeaLevel Changes: An Integrated Approach. Spec. Publ.-Soc. Econ. Paleontol. Mineral., 42:329-353.

Greenlee, S.M., Schroeder, F.W., and Vail, P.R., 1988. Seismic stratigraphic and geohistory analysis of Tertiary strata from the continental shelf off New Jersey: calculation of eustatic fluctuations from stratigraphic data. In Sheridan, R.E., and Grow, J.A. (Eds.), The Atlantic Continental Margin. Geol. Soc. Am., Geol. North Am. Ser., 437-444.

Grow, J.A., and Sheridan, R.E., 1988. U.S. Atlantic continental margin; a typical Atlantic-type or passive continental margin. In Sheridan, R.E. and Grow, J.A. (Eds.), The Atlantic Continental Margin: U.S. Geol. Soc. Am., Geol. of North Am. Ser., 1-7.

Haq, B.U., Hardenbol, J. and Vail, P.R., 1987. Chronology of fluctuating sea levels since the Triassic. Science, 235:1156-1167.

Imbrie, J., et al., 1988. Scientific goals of an Ocean Drilling Program designed to investigate changes in the global environment. In Munsch, G.B. (Ed.), Rep. Second Conf. Sci. Ocean Drilling, 15-46.

Loutit, T.S, Hardenbol, J., Vail, P.R., and Baum, G.R., 1988. Condensed sections: the key to age determination and correlation of continental margin sequences. In Wilgus, C.K., Hastings, B.S., Ross, C.A., Posamentier, H.W., Van Wagoner, J., and Kendall, C.G.St.C. (Eds.), Sea-Level Changes: An Integrated Approach. Spec. Publ.-Soc. Econ. Paleontol. Mineral., 42:183-213.

Lyell, C., 1845. The Cretaceous strata of New Jersey. Quat. Jour. Geol. Soc. London, 1:55-60.

Miall, A.D., 1991. Stratigraphic sequences and their chronostratigraphic correlation, J. Sediment. Petrol., 61: 497-505.

Miller, K.G., et al., 1994. Proc. ODP, Init. Repts., 150X: College Station, TX (Ocean Drilling Program).

1996a. Cape May Site Report. Proc. ODP, Init. Repts., 150X (Suppl.): College Station, TX (Ocean Drilling Program).

Miller, K.G., Fairbanks, R.G., and Mountain, G.S., 1987. Tertiary oxygen isotope synthesis, sea-level history, and continental margin erosion. Paleoceanography, 2:1-19.

Miller, K.G., Kent, D.V., Brower, A.N., Bybell, L.M., Feigenson, M.D., Olsson, R.K., and Poore, R.Z., 1990. Eocene-Oligocene sea-level changes on the New Jersey coastal plain linked to the deep-sea record. Geol. Soc. Am. Bull., 102:331-339.

Miller, K.G., Liu, C., and Feigenson, M.D., 1996b. Oligocene to middle Miocene Sr-isotopic stratigraphy of the New Jersey continental slope. In Mountain, G.S., Miller, K.G., Blum, P., Poag, C.W., and Twichell, D.C. (Eds.), Proc. ODP, Sci. Results, 150: College Station, TX (Ocean Drilling Program), 97-114.

Miller, K.G., and Mountain, G.S., 1994. Global sea-level change and the New Jersey margin. In Mountain, G.S., Miller, K.G., Blum, P., et al., Proc. ODP, Init. Repts., 150: College Station, TX (Ocean Drilling Program), $11-20$.

Miller, K.G., Mountain, G.S., Blum, P., Gartner, S., Alm Per G., Aubry, M.-P., Burckle, L.H., Guerin, G., Katz, M.E., Christensen, B.A., Compton, J., Damuth, J.E., Deconinck, J.F., de Verteuil, L., Fulthorpe, C.S., Hesselbo, S.P., Hoppie, B.W., Kotake, N., Lorenzo, J.M., McCracken, S., McHugh, C.M., Quayle, W.C., Saito, Y., Snyder, S.W., ten Kate, W.G., Urbat, M., Van Fossen, M.C., Vecsei, A., Sugarman, P.J., Mullikin, L., Pekar, S., Browning, J.V., Liu, C., Feigenson, M.D., Goss, M., Gwynn, D., Queen, D.G., Powars, D.S., Heibel, T.D., Bukry, D., 1996c. Drilling and dating New Jersey Oligocene-Miocene sequences: ice volume, global sea level, and Exxon records. Science, 271:1092-1095.

Miller, K.G., and Sugarman, P.J., 1995. Correlating Miocene sequences in onshore New Jersey boreholes (ODP Leg 150X) with global $\delta^{18} \mathrm{O}$ and Maryland outcrops. Geology, 23:747-750. 
Miller, K.G., Wright, J.D., and Fairbanks, R.G., 1991. Unlocking the Ice House: Oligocene-Miocene oxygen isotopes, eustasy, and margin erosion. J. Geophys. Res., 96:6829-6848.

Mountain, G.S., Miller, K.G., Blum, P., et al., 1994. Proc. ODP, Init. Repts., 150: College Station, TX (Ocean Drilling Program).

Olsson, R.K., 1991, Cretaceous to Eocene sea-level fluctuations on the New Jersey margin. Sediment. Geol., 70:195-208.

Olsson, R.K., Melillo, A.J., and Schreiber, B.L., 1987. Miocene sea level events in the Maryland coastal plain and the offshore Baltimore Canyon trough. In Ross, C., and Haman, D. (Eds.), Timing and Depositional History of Eustatic Sequences: Constraints on Seismic Stratigraphy. Spec. Publ. Cushman Found. Foraminiferal Res., 24:85-97.

Olsson, R.K., Miller, K.G., and Ungrady, T.E., 1980. Late Oligocene transgression of middle Atlantic coastal plain. Geology, 8:549-554.

Olsson, R.K., and Wise, S.W., 1987. Upper Paleocene to middle Eocene depositional sequences and hiatuses in the New Jersey Atlantic Margin. In Ross, C., and Haman, D. (Eds.), Timing and Depositional History of Eustatic Sequences: Constraints on Seismic Stratigraphy. Spec. Publ. Cushman Found. Foraminiferal Res., 24:99-112.

Owens, J.P., Bybell, L.M., Paulachok, G., Ager, T.A., Gonzalez, V.M., and Sugarman, P.J., 1988. Stratigraphy of the Tertiary sediments in a 945foot-deep core hole near Mays Landing in the southeastern New Jersey Coastal Plain. Geol. Surv. Prof. Pap. U.S., 1484.

Owens, J.P., and Gohn, G.S., 1985. Depositional history of the Cretaceous series in the U.S. coastal plain: stratigraphy, paleoenvironments, and tectonic controls of sedimentation. In Poag, C.W. (Ed.), Geologic Evolution of the United States Atlantic Margin: New York (Van Nostrand Reinhold), 25-86.

Owens, J.P., and Sohl, N.F., 1969. Shelf and deltaic paleoenvironments in the Cretaceous-Tertiary formations of the New Jersey Coastal Plain. In Subitzky, S. (Ed.), Geology of Selected Areas in New Jersey and Eastern Pennsylvania and Guidebook of Excursions: New Brunswick, NJ (Rutgers Univ. Press), 235-278.

Owens, J.P., Sugarman, P.J., Sohl, N.F, Parker, R., Houghton, H.H., Volkert, R.V., Drake, A.A., and Orndorff, R.C., 1995. Geologic map of New Jersey: Central Sheet. Open-File Rep.-U.S. Geol. Surv., 95-253.

Pekar, S., and K.G. Miller, 1996. New Jersey Oligocene "Icehouse" sequences (ODP Leg 150X) correlated with global $\delta^{18} \mathrm{O}$ and Exxon eustatic records. Geology, 24:567-570.

Poag, C.W., Powars, D.S., Poppe, L.J., Mixon, R.B., Edwards, L.E., Folger, D.W., and Bruce, S., 1992. Deep Sea Drilling Project Site 612 bolide event: new evidence of a late Eocene impact-wave deposit and a possible impact site, U.S. east coast. Geology, 20:771-774.

Poag, C.W., Watts, A.B., et al., 1987. Init. Repts. DSDP, 95: Washington (U.S. Govt. Printing Office).

Poore, R.Z., and Bybell, L., 1988. Eocene to Miocene biostratigraphy of New Jersey core ACGS\#4: implications for regional stratigraphy. U.S. Geol. Surv.

Posamentier, H.W., Jervey, M.T., and Vail, P.R., 1988. Eustatic controls on clastic deposition, I. Conceptual framework. In Wilgus, C.K., Hastings, B.S., Ross, C.A., Posamentier, H.W., Van Wagoner, J., and Kendall, C.G.St.C. (Eds.), Sea-Level Changes: An Integrated Approach. Spec. Publ.-Soc. Econ. Paleontol. Mineral., 42:109-124.

Reynolds, D.J., Steckler, M.S., and Coakley, B.J., 1991. The role of the sediment load in sequence stratigraphy: the influence of flexural isostasy and compaction. J. Geophys. Res., 96:6931-6949.

Sahagian, D.L., and Watts, A.B. 1991. Introduction to the special section on measurement, causes, and consequences of long-term sea level changes. J. Geophys. Res., 96:6585-6589.

Sea-Level Working Group, 1992. JOIDES J., 18:28-36.

Scholle, P.A. (Ed.), 1977. Geological studies on the COST No. B-2 well, U.S. mid-Atlantic outer continental shelf area. Geol. Surv. Circ. (U.S.), 750:35-36.

Shackleton, N.J., and Opdyke, N.D., 1973. Oxygen isotope and paleomagnetic stratigraphy of equatorial Pacific core V28-238: oxygen isotope temperatures and ice volumes on a $10^{5}$ year and $10^{6}$ year scale. Quat. Res., 3:39-55.

Sloss, L.L., 1963. Sequences in the cratonic interior of North America. Geol. Soc. Am. Bull., 74:93-114.

Snyder, S.W, Miller, K.G., and Saperson, E., 1996. Paleogene and Neogene planktonic foraminiferal biostratigraphy of the New Jersey continental slope: Sites 902, 903, and 904 (Leg 150). In Mountain, G.S., Miller, K.G., Blum, P., Poag, C.W., and Twichell, D.C. (Eds.), Proc. ODP, Sci. Results, 150: College Station, TX (Ocean Drilling Program), 3-15.

Steckler, M.S., and Watts, A.B., 1982. Subsidence history and tectonic evolution of Atlantic-type continental margins. In Scrutton, R.A. (Ed.), Dynamics of Passive Margins. AGU Geodyn. Ser., 6:184-196.

Stille, H. 1924. Grundfragen der Vergleichenden Tektonik, Berlin (Borntraeger). Suess, E., 1885, Da Antlitz de Erde, 1. Prague: F. Tempsky.

Sugarman, P.J., Brenner, G., Owens, J.P., and Miller, K.G., 1995. Palynologic and climatic records, New Jersey Coastal Plain: evidence for late early Miocene climatic transition. Geol Assoc. New Jersey Rept, XII:269-285.

Sugarman, P.J., and Miller, K.G., 1997. Correlation of Miocene global sequences and hydrostratigraphic units, New Jersey coastal plain. Sed. Geology. 108:3-18.

Sugarman, P.J., Miller, K.G., Bukry, D., and Feigenson, M.D., 1995. Uppermost Campanian-Maestrichtian strontium isotopic, biostratigraphic, and sequence stratigraphic framework of the New Jersey Coastal Plain, Geol. Soc. Am. Bull., 107:19-37.

Sugarman, P.J., Miller, K.G., Owens, J.P., and Feigenson, M.D., 1993. Strontium isotope and sequence stratigraphy of the Miocene Kirkwood Formation, Southern New Jersey. Geol Soc. Am. Bull., 105:423-436.

Sugarman, P.J., Owens, J.P., and Bybell, L.M., 1991. Geologic map of the Adelphia and Farmingdale Quadrangles, Monmouth and Ocean Counties, New Jersey. New Jersey Geol. Surv., Geologic Map Series, 91-1.

Vail, P.R., Mitchum, R.M., Jr., Todd, R.G., Widmier, J.M., Thompson, S., III, Sangree, J.B., Bubb, J.N., and Hatlelid, W.G., 1977. Seismic stratigraphy and global changes in sea level. In Payton, C.E. (Ed.), Seismic Stratigraphy: Applications to Hydrocarbon Exploration. AAPG Mem., 26:49-221.

Van Fossen, M.C., and Urbat, M., 1996. Magnetostratigraphy of Miocene and Pleistocene sediments on the New Jersey slope. In Mountain, G.S., Miller, K.G., Blum, P., Poag, C.W., Twichell, D.C. (Eds.), Proc. ODP, Sci. Results, 150: College Station, TX (Ocean Drilling Program), 129-143.

van Hinte, J.E., Wise, S.W., Jr., et al., 1987. Init. Repts. DSDP, 93 (Pts. 1 and 2): Washington (U.S. Govt. Printing Office)

Watkins, J.S., and Mountain, G.S. (Eds.), 1990. Role of ODP Drilling in the Investigation of Global Changes in Sea Level. Rep. JOI/USSAC Workshop, El Paso, TX, Oct. 24-26, 1988.

Watts, A.B., 1982. The U.S. Atlantic continental margin: subsidence history, crustal structure and thermal evolution. In Bally, A.W. et al., Geology of Passive Continental Margins, AAPG Education Course Note Series, 19:i-75.

Watts, A.B., and Steckler, M.S., 1979. Subsidence and eustasy at the continental margin of eastern North America. In Talwani, M., Hay, W., and Ryan, W.B.F. (Eds.), Deep Drilling Results in the Atlantic Ocean: Continental Margins and Paleoenvironment. Am. Geophys. Union, Maurice Ewing Ser., 3:218-234.

Wright, J.D., and Miller, K.G., 1992. Miocene stable isotope stratigraphy, Site 747, Kerguelen Plateau. In Wise, S.W., Jr., Schlich, R., et al., Proc. ODP, Sci. Results, 120: College Station, TX (Ocean Drilling Program), 8 $55-866$.

Date of initial receipt: 1 February 1996

Date of acceptance: 30 August 1996

Ms 150XSR-301 